\title{
The Development of Interactive Multimedia Using Lectora Inspire Application in Arabic Language Learning
}

\author{
Adam Mudinillah \\ Institut Agama Islam Negeri Batusangkar, Indonesia
}

Corresponding Author: Adam Mudinillah, @ad4mmudinillah@gmail.com

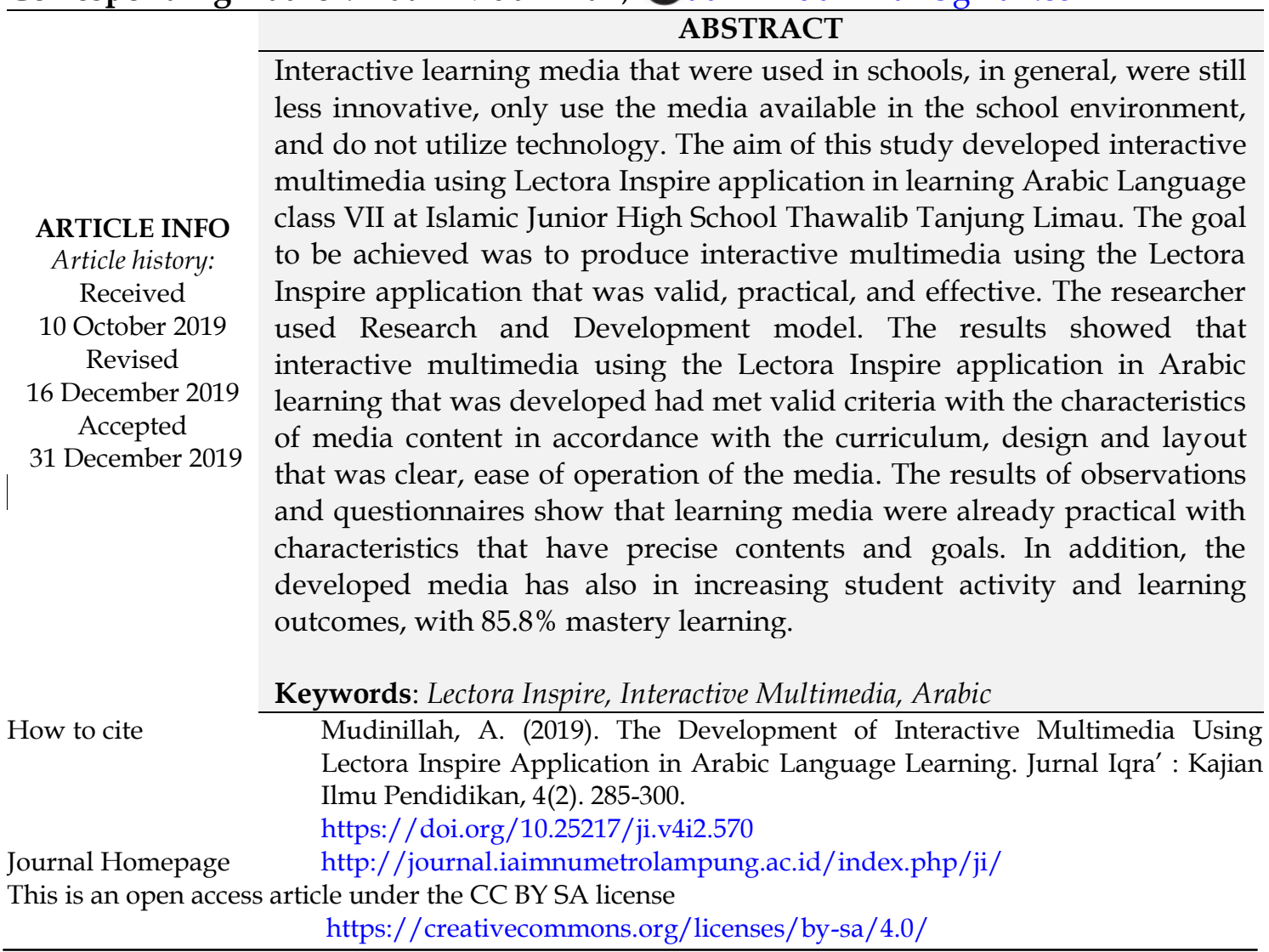

\section{INTRODUCTION}

Advances in technology have a positive impact on education. Information technology, especially computer technology both in hardware and software, as well as mobile learning, learning media and applications that provide many offers and choices for the world of education to support the learning process (Hamidi \& Chavoshi, 2018; Bulman \& Fairlie, 2016; Song, Kalet, \& Plass, 2016; Fernandes, Arriaga, \& Esteves, 2015). Such as the use of media in learning Arabic must also be the center of attention for teachers because the media is one of the means for the achievement of learning objectives. Learning Arabic, it is necessary to combine the use of various and innovative learning media. Thus, it will help students understand abstract concepts. It closely connected with the opinions of Fisch et al., (2014), designing in multiple media learning platforms 
can produce interactive media to develop students' learning. Moreover, the utilization and development of interactive learning media become a fundamental requirement in supporting the effectiveness and quality education process (Fisch et al., 2014; Kraiger, et al., 2014). So that the learning process is easy to do, and learning objectives can be adequately achieved. Therefore a teacher is required to be able to design a variety of instructional media that can support and motivate students in learning so that excellent communication is established between students and teachers in the learning process. One of the benefits of using media in education is to improve learning experiences to be more concrete or to be able to concretize learning materials that are abstract and complex.

Technological progress is very beneficial for educators if it is truly utilized. And the most important thing is that a teacher can apply technology and learning strategies in enhancing the teaching and learning process (Keengwe, 2015). Unfortunately, the teachers at Junior High School of Thawalib Tanjung Limau use very little technology because teachers lack knowledge in the field of media and the leadership of the principal is very little enthusiasm in the field of technology. It was explained by the teacher of the field of study that the school had never held learning media training and also had never sent or recommended education to attend media training courses.

As the result, the implementation of Arabic learning in schools does not appropriate result for students and teachers. Many factors cause obstacles in the process of implementing Arabic learning in schools. Teachers rarely use learning media and only occasionally Arabic language teachers use the media using PowerPoint applications. The media results are not include in the appropriate category in learning Arabic. Based on the facts, it is known that Arabic learning outcomes obtained by students in these schools can be seen in the following table:

Table 1. Score of Arabic Learning Outcomes Islamic Junior High School (MTs) Thawalib Tanjung Limau

\begin{tabular}{|c|c|c|}
\hline No & Class & Average \\
\hline 1 & VII. 1 & 7.25 \\
\hline 2 & VII. 2 & 7.05 \\
\hline 3 & VII. 3 & 6.95 \\
\hline \multicolumn{2}{|c|}{ Total } & 21.25 \\
Average & 7.08 \\
\hline
\end{tabular}


Based on Table I above, the average acquisition of student grades in class VII, ranged from 6.95 to 7.25. This data shows that the average value of Arabic Language students still have not reached KKM (KKM value is 7.5). At the same time, the general goal of learning Arabic is students master and can practice four language skills, namely: Istima '(Listening / Listening), Kalam (Speaking), Qiro'ah (Reading), and Kitabah (Writing). In addition, students must also master in three components of language, for instance Ashwaat (Phonology), Mufrodat (Vocabulary), and Qowa'id / Tarkib (Grammar) ".

Based on the observations at the school. The researcher found that; (1) the teacher has been able to operate a computer, (2) the teacher has conducted training media for learning organized by the relevant agencies; and (3) the teacher has not found an effective learning media to deliver the subject matter; and Whereas students, namely: (1) have often operated computers; (2) the enthusiasm of students to take part in learning to use a computer is low; and (3) students need a variety of media in learning, while the school has fulfilled a suitable laboratory for learning using interactive multimedia.

One of way to overcome these problems is using learning media in the form of interactive multimedia. Characteristics Multimedia can increase motivation and effectiveness of learning outcomes for users (Susilana 2008). Multimedia is a combination of text, images, video, sound and animation. Interactive multimedia that was developed in this research was a combination of Lectora Inspire, Adobe Photoshop, Corel Draw, Any Video Converter, Snagit, Camtasia, Ply Paper, and Wondershare Filmmora Software. The software supports the development of interactive multimedia that contains text, images, videos, sounds and animations. Through the use of a combination of this software, interactive multimedia can be designed and packaged as attractive as possible. Thus, students are happy and not bored to learn. The development Interactive multimedia media can be used to provide concrete, accordance with the characteristics of VII grade students of Islamic Junior High School (MTs). The objects that cannot be brought into the class can be presented using interactive multimedia.

Several previous studies have discussed the use of the Lectora Inspire application in the learning process. Nasution, Silaban, \& Sudraja (2018) discussed the Influence of Problem Based Learning, Guided Inquiry Learning Models Assisted by Lectora Inspire, and Scientific Attitudes to Student's Cognitive Values. This study reported that the Problem Based Learning (PBL) learning model assisted by Lectora Inspire media, Guided Inquiry (GI) learning model was supported by Lectora Inspire media, and students 'attitudes towards students' cognitive values on colloidal system material. These findings were

\section{7}


that there were no significant differences in cognitive values of students who were taught using PBL learning models assisted by Lectora Inspire media with the Lectora Inspire media supported GI learning models on colloid system material. Further, by Yasmar (2017) on Interactive Multimedia Learning Arabic Language For Aliyah Madrasah Students, Stated that the results of the study indicate the expert assessment of the material on the feasibility of Interactive Learning Arabic Language CDs from the learning aspect with an average of 4.17 (good) and material aspects with a mean of 4.00 (good). Next, a study conducted by Wijoyo (2016) on the Development of E-Learning Learning Media for Arabic Reading Skills for Class VIII. The result showed the assessment of media experts and material experts shows the results of conformity in the E-Learning media. Hypothesis test results are accepted, with details of the results of the right-side hypothesis test generated from the value of students working on the test problems showed $t$ arithmetic 18,158, and the results of student assessment through a questionnaire showed $\mathrm{t}$ arithmetic 35.05. Everything falls in the area of Ha acceptance, so Ha is accepted, and new products are more effective than old products. Oktaria (2016) also reported that an increase in student interest in learning after the end of the action by using the media Lectora Inspire. The material presented through Lectora Inspire is equipped with various animations, images, colours and sounds, so it does not make students bored. When learning in the class, the students form discussion groups in the learning process. And there is a discussion guide on Lectora Inspire displayed on a projector. The things that make students feel interested in learning Arabic by using the Lectora Inspire media, those are: reward in the form of praise and applause, reinforcement, teachers motivate students more, create an atmosphere of active and fun learning.

Previous studies above gave an impact in increasing students' learning and interactive media, but did not integrate in other some media to develop their learning. While this current studies more interactive in applying of learning media which developed in combination of some software, for instance Lectora Inspire, Adobe Photoshop, Snagit, Camtasia, Ply Paper, Corel Draw, Any Video Converter, and Wondershare Filmmora Software. Using the combination of this software, interactive multimedia can be designed and packaged as attractive as possible. The software supports the development of interactive multimedia that contains text, images, videos, sounds and animations. On the other hand, this research used Islamic value in the content of materials on Lectora Inspire application. It can be proven that the use of the Lectora Inspire application in learning helps teachers to improve student understanding in education and learning media play an essential role in

\section{8}


delivering material. Hence, students easily understand abstract material, cannot be seen directly by the senses and brought into class. The teacher must be creative and innovative in choosing appropriate media to convey the subject matter. So that learning objectives are achieved and have a positive impact on student learning outcomes. The teacher must also make the Arabic learning process more interesting, more innovative and enjoyable.

Based on the description above, it can be concluded that learning media needs to be optimized in learning Arabic because Arabic material cannot be presented using printed books and teacher lectures only. The media also needs to optimize the use of technology to make it more varied and enjoyable, especially at schools already equipped with facilities and infrastructure in the form of computers and projectors. Media must be able to provide direct experience to students. Thus, it has a good impact on student learning outcomes. Learning media are all things that can bring information or messages in interaction in the learning process (Azhar, 2014). A good application of learning media requires the ability of teachers to design and develop learning tools in the form of learning models that can help students and teachers in the learning process (Maulana, Hary, Purwasih, \& Firdian, 2019).

The use of interactive multimedia can use a laptop or computer. For delivering material in class, the teacher can use the LCD projector to display multimedia visuals and speakers for sound output in front of the class. The use of interactive multimedia users does not have to install Lectora Inspire software, Adobe Photoshop, Corel Draw, Any Video Converter, Snagit, Camtasia, Ply Paper, Wondershare Filmmora and Auda City. It is because interactive multimedia is packaged in exe format. So that it can be directly run without installing each of this software. The learning process using interactive media can have a significant influence on student motivation and learning outcomes. It was closely connected with research conducted by Maulana et al., (2019), the results of his research obtained interactive multimedia is very effective in improving student learning outcomes. If students have high enjoyment in learning, of course, the learning material delivered will be more easily absorbed by students (Darmansyah, 2018). One of the objectives of this development research was to develop interactive media in interactive multimedia-based Arabic learning that can be utilized in learning Arabic.

\section{RESEARCH METHODOLOGY}

Development research was the activity of collecting, processing, analyzing, and presenting data carried out systematically and objectively. Product development was to solve a problem in learning process. The 
researcher used Research and Development to develop interactive media in interactive multimedia-based Arabic learning that can be utilized in learning Arabic. Research and Development is research that produces certain products and tests the effectiveness of these products (Maulana, 2017). The development of instructional media focused on interactive multimedia-based learning media that were valid, practical, and effective for VII grade students of Islamic Junior High School (MTs). Thus, it is a systematic study of complete scientific knowledge or understanding of the subject under study. Development research is a research method that is used to develop a product through certain stages until later produced products that are tested the level of validity, practicality, and effectiveness of needs. The 4-D Model consists of four stages: defining, designing, developing, and disseminating) (Trianto, 2011).

Data collection techniques were questionnaire, observation sheet and student learning outcomes test. The type of data which was used in the development of this media was primary data: The data was obtained directly from research validator, students and teachers through a questionnaire testing the validity, practicality, and effectiveness of the learning media developed.

Validation data was obtained through a questionnaire containing expert responses about the assessment of aspects of media quality, material and language from instructional media. The validation sheet contains items that state the validity of the media, the content and language of the learning media, learning media such as the programming aspects used. The research instrument in the form of a questionnaire based on the lattice that has been developed is modified from Walker and Hess (Azhar, 2015). And questionnaire responses to the assessment of interactive media in learning Arabic based on interactive multimedia (practicality questionnaire) are conducted by teachers and students to find out the ease and practicality of the developed media. The teacher practicality sheet is filled in by the teacher about the ease of use of the learning media used, as well as the attractiveness of the learning media. While the media practicality sheet by students is filled in by students, this practicality sheet contains about the ease of students in understanding the material, as well as the attractiveness of learning media. This practical instrument was also compiled using a Likert Scale with alternative answers strongly agree, agree, disagree, disagree, and strongly disagree (Richey \& Klein, 2014). While, the effectiveness development product of interactive media was analyzed from the students' learning result through the test of learning outcomes of each student on Arabic Al-Alwan material. The evaluation which was used to obtain data on student learning outcomes was an evaluation conducted at the end of learning. The data analysis technique used was descriptive qualitative, which is aimed to explain 
the learning media products developed and quantitative descriptive of the feasibility of the products implemented in learning.

\section{RESULTS AND DISCUSSION}

\section{Validity}

Learning media that have been developed are said to be valid if they meet specific criteria. The purpose of the validity test is to get the validity and validity of the data information obtained. The validation carried out in this study was media validation. The validation of learning media uses the Lectora Inspire application in terms of media, content or language.

The expert validator in each validation instrument was carried out by three people. Product validation can be done by several experts to assess the product being designed so that the weaknesses and their strengths can be further identified (Tarsito, 2014). The result of expert validation collected and then analyzed to find an average of each aspect. The validation results were described as follows:

The development of interactive media using the Lectora Inspire application in Arabic class VII subjects was carried out by testing the validity of the product by media experts from the aspect of media, content or material, and language to prove whether there was the eligibility for media development in accordance with media eligibility criteria. Data collection instruments used in the form of assessment sheets for experts.

The average score for the assessment of product development interactive media using the Lectora Inspire application was obtained score 100, Material aspects was score 95, and Language aspects score 93.8. Overall Interactive multimedia products that have been developed are valid. It was based on the results of the validity of the media. It contains the suitability of the media, design and layout as well as the operation of interactive multimedia obtained an average value of $96.2 \%$. The recapitulation of the results of the learning media validation using the Lectora Inspire application can be seen in Table 2:

Table 2. Assessment Results

\begin{tabular}{|c|c|c|}
\hline Assessment aspect & Rating & Category \\
\hline Media & $100 \%$ & Very Valid \\
\hline Material & $95 \%$ & Very Valid \\
\hline Language & $93,8 \%$ & Very Valid \\
\hline Amount & \multicolumn{2}{|c|}{288,8} \\
\hline Average & $96,2 \%$ & Very Valid \\
\hline
\end{tabular}


Based on the results of validation, it can be concluded that the developed interactive media was appropriate with curriculum. The presentation of material was appropriate with the indicator which was formulated in the following of students' development. The content of learning media was also appropriate with Arabic learning material in class VII MTs. Various concepts and job descriptions contained in interactive multimedia make it easy for students in understanding of Al-Alwan material. Use of language was simple and easy understanding for students. The development media were designed with attractive colors, various images and videos; it is expected to motivate students to understand the learning material well. So, it can be concluded that interactive media in learning Arabic using the Lectora Inspire application was developed and declared valid. It can be used in the learning process.

\section{Practicality}

Analyzing the practicality level of interactive media using the Lectora Inspire application practically or not, a trial was conducted on Grade VII students of MTs Thawalib Tanjung Limau on Arabic subjects.

The researchers gave questionnaire responses of teachers and students towards the learning media practicality:

The Results Analysis of Teacher Responses to the Practicality of Interactive Media in Learning Arabic using the Lectora Inspire application

Teacher response assessment aimed to determine the teacher's opinion on the practicality of developed learning media. The results of the practicality assessment of Arabic learning media in learning Arabic using the Lectora Inspire application in class VII MTs can be presented as follows: 
The Development of Interactive Multimedia Using Lectora Inspire Application in Arabic Language Learning

Table 3. Teachers' Response Results to the Practicality of Learning Media.

\begin{tabular}{|c|c|c|}
\hline No & Assessment Aspects & Score \\
\hline 1 & Ease of operation of interactive multimedia & 4 \\
\hline 2 & Ease of understanding button layout & 4 \\
\hline 3 & Interactive multimedia helps in understanding the material & 4 \\
\hline 4 & Presentation of pictures / videos is good & 3 \\
\hline 5 & Music used in attractive interactive multimedia & 3 \\
\hline 6 & Interactive multimedia can increase motivation in learning & 4 \\
\hline 7 & $\begin{array}{l}\text { Interactive multimedia can be used for independent } \\
\text { learning }\end{array}$ & 4 \\
\hline 8 & Images used in attractive interactive multimedia & 4 \\
\hline 9 & Videos used in attractive interactive multimedia & 3 \\
\hline 10 & Text colors used in attractive interactive multimedia & 3 \\
\hline 11 & Background used in attractive interactive multimedia & 4 \\
\hline 12 & The layout of the presentation of material is good and right & 4 \\
\hline 13 & The language used is easy to understand & 4 \\
\hline 14 & Interactive multimedia provides comfort in learning & 4 \\
\hline \multicolumn{2}{|c|}{ Total Score } & 52 \\
\hline \multicolumn{2}{|c|}{$\begin{array}{l}\text { Total } \\
\text { Overall Media Validity Value }\end{array}$} & 100 \\
\hline \multicolumn{2}{|c|}{ Criteria } & $\begin{array}{c}\text { Very } \\
\text { Practical }\end{array}$ \\
\hline
\end{tabular}

Table 3 reported that the average percentage of teachers' response evaluations to interactive media in learning Arabic using the Lectora Inspire application was $100 \%$ in the category of practically efficient. It means that interactive media in learning Arabic using the Lectora Inspire application was categorized very practical. Very practical means that 
interactive media using the Lectora Inspire application complies with predetermined criteria.

Student responses to student practicality were given to find out students' opinions about the practicality of learning media using the Lectora Inspire application. 20 students filled this practicality sheet at the final trial meeting. Analyzing the data obtained each assessment of student responses to the practicality of learning media. In summary, the results of the practicality of student responses to interactive media using Lectora Inspire application can be seen in Table 4 below:

Table 4. Students' Responses to the Practicality of Learning Media

\begin{tabular}{|c|c|c|}
\hline No & Assessment Aspects & Skor \\
\hline 1 & Ease of operation of interactive multimedia & 4 \\
\hline 2 & Ease of understanding button layout & 3 \\
\hline 3 & Interactive multimedia helps in understanding the material & 4 \\
\hline 4 & Presentation of picture or video is good & 4 \\
\hline 5 & Music used in attractive interactive multimedia & 4 \\
\hline 6 & Interactive multimedia can increase motivation in learning & 3 \\
\hline 7 & Interactive multimedia can be used for independent learning & 3 \\
\hline 8 & Images used in attractive interactive multimedia & 4 \\
\hline 9 & Videos used in attractive interactive multimedia & 4 \\
\hline 10 & Text colors used in attractive interactive multimedia & 3 \\
\hline 11 & $\begin{array}{l}\text { Background used in attractive interactive multimedia } \\
\text { Interesting }\end{array}$ & 3 \\
\hline 12 & The layout of the presentation of material is good and right & 4 \\
\hline 13 & The language used is easy to understand & 4 \\
\hline 14 & Interactive multimedia provides comfort in learning & 4 \\
\hline \multicolumn{2}{|r|}{ Total Score } & 51 \\
\hline \multicolumn{2}{|r|}{ Total Score of Validity } & 98,1 \\
\hline \multicolumn{2}{|r|}{ Criteria } & $\begin{array}{c}\text { Very } \\
\text { Practical }\end{array}$ \\
\hline
\end{tabular}


Based on the table above it can be presented that the percentage of student responses to the practicality of instructional media in using the Lectora Inspire application was $98.1 \%$ with an efficient category. It can be concluded that the interactive media in learning Arabic using the Lectora Inspire application was categorized as very practice because the media attracts the attention. It increases student motivation, learning material that was closely related to student's life, material, instructions, and stages of activities were easily understood. In addition, interactive media using the Lectora Inspire application increases student participation and activity.

\section{Effectiveness}

The results of the development of interactive media in learning Arabic using the Lectora Inspire application can be measured through the validity, practicality, and effectiveness of learning media using the Lectora Inspire application that was developed. Effectiveness can be done if the developed product was and practical. The effectiveness of interactive media using the Lectora Inspire application can be seen through the assessment of student activities and learning outcomes. The effectiveness of learning was characterized by a) successfully delivering students to achieve instructional goals that have been set, b) providing an attractive learning experience, involving students actively to support the achievement of instructional goals, c) having facilities that support the learning process (Yaumi, 2017).

Based on the results of the effectiveness test at the development stage shows the average results of learning Arabic students have shown a good percentage. The results of data analysis of student activities during the learning process at the trial school obtained an average value of $91.5 \%$. In the assessment of Arabic learning outcomes of students in the trial, the school got an average value of 87.2 with an excellent category.

The finding of this study showed that interactive learning media using Lectora Inspire in learning Arabic developed has a valid assessment with the characteristics of media content that was in accordance with the curriculum, design and layout. It was clear, easy to understand the media, clear in using language, easy, and the presentation is clearly adjusted to student characteristics. Observations and questionnaires show that learning media that are already practical with characteristics have clear, readable, interesting and interesting contents and can increase attractiveness and interest of students to learn Arabic. In addition, the developed media also has an effectiveness in increasing student activity and learning outcomes with a mastery level of 
learning $85.8 \%$, it was undeniable that interactive learning media in learning Arabic using Lectora Inspire developed for Grade VII students was valid, practical, and effective. This research finding was different from the previous research who conducted by (Rachmadtullah \& Sumantri, 2018). Because this research focused on development interactive learning media using computerbased learning software and the participants was elementary education. While this research focused on the development Lectora Inspire Application for Islamic junior high school on Arabic language subject, specifically on Al-Alwan material. The different was in conducted observation that consist of five activities involve Visual Activities, namely paying attention to learning media using the application Lectora Inspire, (2) Listening Activities, namely listening to the teacher's explanation, (3) Oral Activities, namely asking questions or giving opinions, (4) Writing Activities, doing exercises on learning media using the application Lectora Inspire, (5) Motor Activities, doing steps on learning media using the application Lectora Inspire. Further, the different research from Adisaputera, Saragih (2019) who reported that that the development of interactive media in learning focus on reading text utilize local wisdom as source of content value. While this current research utilizes Islamic value as source of content value in lectora inspire application. The learning process was more interesting, interactive, and the quality and attitude of student learning can be improved, and the learning process can be done anywhere and anytime. It was accordance with the opinion of Kristanto (2017) which states that learning will be effective if carried out in a pleasant atmosphere. If students have high enjoyment in learning, of course the learning material delivered will be more easily absorbed by students. According to Sari, et al (2019) said that interactive multimedia was a combination of text, art, sound, images, animation and video that was packaged with the help of computers and interactively controlled. It aimed to present information in a form that was fun, interesting, easy to understand, and clear. The Information would be easy to understand because as many senses as possible, especially to absorb information. Learning media is everything that can bring information or messages in interaction in the learning process. The use of learning resources and learning media is a strategy in learning. The use of media in learning provides stimuli to students who receive responses with different characteristics of each individual.

\section{CONCLUSION}

The test results show that learning media products use the Lectora Inspire application in all aspect. Those are the terms of practicality, ranging from ease of use, benefits, appearance and time, based on the teacher's view, the value of

\section{6}


90 with very good criteria and the value of 90.2 with very good criteria is obtained from in terms of students. The effectiveness test was carried out in class VII MTs Thawalib Tanjung Limau. It was obtained 20 people with a result of 1745 with an average learning result of 87.2. Based on the comparison of learning outcomes with student midterm scores, it appears that interactive media in learning Arabic using the Lectora Inspire application in class VII MTs can increase learning motivation and help students understand learning material.

\section{ACKNOWLEDGEMENTS}

The author was grateful to the Headmaster of Islamic Junior High School (MTs) Thawalib Tanjung Limau who has given permission to conduct this research. And everyone thanks who has contribute their thought, time and energy to help finish this research.

\section{AUTHOR CONTRIBUTION STATEMENTS}

The author had participated in the research and approved the final version of the manuscript.

\section{REFERENCES}

Azhar, A. (2014). Media pembelajaran. Jakarta: Rajawali Press.Google Scholar. Bulman, G., \& Fairlie, R. W. (2016). Chapter 5 - Technology and Education: Computers, Software, and the Internet. In E. A. Hanushek, S. Machin, \& L. Woessmann (Eds.), Handbook of the Economics of Education (Vol. 5, pp. 239-280). https:/ / doi.org/10.1016/B978-0-444-63459-7.00005-1.

Darmansyah, S. T. (2018). Menciptakan pembelajaran menyenangkan melalui optimalisasi jeda strategis dengan karikatur humor dalam belajar matematika. Jurnal Teknodik, 21(3), 039067.https:// doi.org/10.32550/teknodik.v21i3.461.

Fariyatul, E., \& Bandono, A. (2017). The use of value clarification techniquebased-picture story media as an alternative media to value education in primary school. HARMONIA: Journal of Arts Research and Education, 17(1), 68-74. https:// doi.org/10.15294/harmonia.v17i1.7469

Fernandes, S., Arriaga, P., \& Esteves, F. (2015). Using an Educational Multimedia Application to Prepare Children for Outpatient Surgeries. Health Communication, 30(12), 1190-1200. https:/ / doi.org/10.1080/10410236.2014.896446. 
Fisch, S. M., Lesh., Motoki, E.., Crespo, S, \& Melfi,. (2014). Cross-platform learning: How do children learn from multiple media. Learning by playing: Video gaming in education, 207-219. Google Scholar.

Hamidi, H., \& Chavoshi, A. (2018). Analysis of the essential factors for the adoption of mobile learning in higher education: A case study of students of the University of Technology. Telematics and Informatics, 35(4), 10531070. https:/ / doi.org/10.1016/j.tele.2017.09.016.

Keengwe, J. (Ed.). (2015). Handbook of research on educational technology integration and active learning. IGI Global. Google Scholar.

Kraiger, K., Passmore, J., Dos Santos, N. R., \& Malvezzi, S. (Eds.). (2014). The Wiley Blackwell handbook of the psychology of training, development, and performance improvement. John Wiley \& Sons. Google Scholar.

Kristanto, A. (2017). The Development of Instructional Materials E-Learning Based on Blended Learning. International Education Studies, 10(7), 10-17. Google Schoolar.

Yaumi, M. (2017).Prinsip Prinsip Design Pembelajaran, Disesuaikan dengan kurikulum 2013, edisi ke dua, Jakarta:Kencana.Google Scholar.

Maulana, I. T. (2017). Pengembangan Media Pembelajaran CD Interaktif Mata Diklat Jaringan Dasar. Indonesian Journal of Computer Science, 6(1), 97. https:// doi.org/10.33022/ijcs.v6i1.4.

Maulana, I. T., \& Hary, R. D. (2019). Pengembangan Perangkat Pembelajaran Berbasis Proyek Mata Diklat Instalasi LAN Jurusan Teknik Komputer dan Jaringan. 2, 196-201. http:/ / dx.doi.org/10.17977/jptpp.v4i2.11973.

Maulana, I. T., Hary, R. D., Purwasih, R., \& Firdian, F. (2019). Project-Based Learning Model Practicality on Local Network Devices Installation Subject. International Journal : Emerging Technologies in Learning (IJET), 14(15), 94-106. http:/ / dx.doi.org/10.29240/jba.v1i2.325.

Nasution, R., Silaban, S., \& Sudrajat, A. (2018). The Influence of Problem Based Learning, Guided Inquiry Learning Models Assited by Lectora Inspire, and Scientific Attitudes to Student's Cognitive Values. 3rd Annual International Seminar on Transformative Education and Educational Leadership (AISTEEL 2018). Atlantis Press. https:// dx.doi.org/10.2991/ aisteel-18.2018.58.

Oktaria, A. (2016). Implementasi lectora inspire sebagai media pembelajaran dalam meningkatkan minat belajar bahasa arab siswa kelas xi agama di man godean. al Mahāra: Jurnal Pendidikan Bahasa Arab, 2(2), 28-49. https:// doi.org/10.14421/almahara.2016.022-02

Rachmadtullah, R., Ms, Z., \& Sumantri, M. S. (2018). Development of computerbased interactive multimedia: study on learning in elementary education. 
The Development of Interactive Multimedia Using Lectora Inspire Application in Arabic Language Learning

Int. J. Eng. Technol, 7(4), 2035-2038. https:// doi.org/10.14419/ijet.v7i4.16384

Sari, A. C., Fadillah, A. M., Jonathan, J., \& Prabowo, M. R. D. (2019). Interactive Gamification Learning Media Application For Blind Children Using Android Smartphone in Indonesia. Procedia Computer Science, 157, 589-595. https:/ / doi.org/10.1016/j.procs.2019.09.018

Song, H. S., Kalet, A. L., \& Plass, J. L. (2016). Interplay of prior knowledge, selfregulation and motivation in complex multimedia learning environments. Journal of Computer Assisted Learning, 32(1), 31-50. https:// doi.org/10.1111/jcal.12117.

Susilana, R., Si, M., \& Riyana, C. (2008). Media pembelajaran: hakikat, pengembangan, pemanfaatan, dan penilaian. CV. Wacana Prima. Google Scholar

Sudjana, N. (2009). Penilaian Hasil Proses Belajar Mengajar. Bandung:Rosdakarya.Google Scholar.

Tarsito, S. (2014). Metode Penelitian Kuantitatif, Kualitatif dan RED. Bandung: Alfabeta.Google Scholar.

Richey, R. C., \& Klein, J. D. (2014). Design and development research: Methods, strategies, and issues. Routledge. Google Scholar.

Suprijono, A. (2011). Model-Model Pembelajaran Inovatif Berorientasi Konstruktivistik. Jakarta: Prestasi Pustaka Publisher. Google Scholar.

Siregar, S. (2015). Statistika terapan untuk perguruan tinggi. Jakarta: Prenadamedia Group.Google Scholar.

Siregar, N. H. O., Adisaputera, A., \& Saragih, A. (2019, December). Development of Interactive Multimedia in Learning to Read Genre Text with Local Wisdom for Students Junior High School Silangkitang. In 4th Annual International Seminar on Transformative Education and Educational Leadership (AISTEEL 2019). Atlantis Press. Google Schoolar.

Wijoyo, T. (2016). Pengembangan Media Pembelajaran E-Learning Berbasis Aplikasi Lectora Inspire Untuk Keterampilan Membaca Bahasa Arab Siswa Mts Kelas Viii. Lisanul' Arab: Journal of Arabic Learning and Teaching, 5 No 1. https:/ / doi.org/10.15294/la.v5i1.10432.

Yasmar, R. (2017). Multimedia Interaktif Pembelajaran Bahasa Arab Untuk Siswa Madrasah Aliyah. ARABIYATUNA: Jurnal Bahasa Arab, 1(2). https:// doi.org/10.29240/jba.v1i2.325.

Yasmar, Renti. 2017. "Multimedia Interaktif Pembelajaran Bahasa Arab Untuk Siswa Madrasah Aliyah." Arabiyatuna: Jurnal Bahasa Arab STAIN Curup. Volume 1. No. 2: 199 - 216. http:/ / dx.doi.org/10.29240/jba.v1i2.325. 
The Development of Interactive Multimedia Using Lectora Inspire Application in Arabic Language Learning

Copyright Holder :

(C) Mudinillah, A. (2019).

First Publication Right :

(C) Jurnal Iqra' : Kajian Ilmu Pendidikan

This article is under:

(ㅇ)(1) (2) 